\title{
INFLUENCE OF HIGH TEMPERATURE PLASMA NITRIDING ON CORROSION RESISTANCE OF X12Cr13 STEEL
}

\author{
Petr FALTEJSEK ${ }^{1}$, David KUSMIČ ${ }^{1}$, Ondřej ČECH ${ }^{2}$ \\ ${ }^{1}$ University of Defence, Department of Mechanical Engineering, Brno, Czech Republic, EU, \\ petr.faltejsek@email.cz, david.kusmic@unob.cz \\ ${ }^{2}$ Brno University of Technology, Department of Electrical and Electronic Technology, Brno, \\ Czech Republic, EU, ondra.cech@seznam.cz
}

https://doi.org/10.37904/metal.2019.897

\begin{abstract}
The martensitic stainless steel AISI 410 was subjected to plasma nitriding at an increased temperature of $550{ }^{\circ} \mathrm{C}, 24 \mathrm{~h}$ in $3 \mathrm{H}_{2}: 1 \mathrm{~N}_{2}(\mathrm{l} / \mathrm{h})$ nitriding gas ratio and compared to untreated one. The microstructure and microhardness of the untreated and nitrided stainless steel were evaluated. The corrosion properties of the untreated and plasma nitrided steel samples were evaluated using the anodic potentiodynamic polarization tests in neutral $2.5 \% \mathrm{NaCl}$ deaerated solution. The phase analysis of nitrided steel sample was compared to untreated one. The results showed that plasma nitriding process on the X12 $\mathrm{Cr} 13$ Steel (AISI 410) stainless steel produced a nitride layer consisting of compound layer and a nitrogen rich diffusion layer with iron carbides $\mathrm{Fe}_{3} \mathrm{C}$, iron nitrides $\mathrm{Fe}_{4} \mathrm{~N}$, chromium nitrides $\mathrm{Cr}_{4} \mathrm{~N}_{4}$ and chromium iron carbide $\mathrm{Cr}_{15} \mathrm{Fe}_{7} \mathrm{C}_{6}$. Plasma nitriding process significantly increased the surface hardness of the martensitic stainless steel but also decreased the corrosion resistance. The pitting and type of corrosion were evaluated, and the pitting coefficient was calculated. During electrochemical corrosion tests, the nitrided AISI 410 stainless steel showed lower corrosion potentials (more negative), higher current densities (nearly forty times higher) and nearly forty times increased corrosion rates compared to untreated $\mathrm{X} 12 \mathrm{Cr} 13$ stainless steel.
\end{abstract}

Keywords: Plasma nitriding, stainless steel, corrosion resistance

\section{INTRODUCTION}

One of the processes of surface treatment based on chemical-heat treatment is the plasma nitriding (PN) process. This PN process is used to improve the mechanical properties such as surface hardness, fatigue strength [1,2] and tribological properties [3,4] of structural steels. On the other hand, some of the mechanical properties, for example notch toughness, are reduced by plasma nitriding process [5]. Plasma nitriding of structural carbon steels is typically carried out in the range of $450 \div 550{ }^{\circ} \mathrm{C}[1,2]$. Increase of corrosion resistance may occur under certain conditions after plasma nitriding in the case of structural steels [6].

The improvement of mechanical properties of plasma nitride stainless steels is similar to the improvement of mechanical propertied of plasma nitrided structural carbon steels. For example, surface hardness is increased rapidly of AISI 410 stainless steel after plasma nitriding at $400{ }^{\circ} \mathrm{C}, 20$ hours and with working atmosphere $1 \mathrm{H}_{2}: 3 \mathrm{~N}_{2}$, up to $1275 \mathrm{HV}$ [3]. The corrosion resistance of stainless steels is directly dependent on plasma nitriding parameters as time duration of process, composition of nitriding (working) atmosphere and especially the temperature of the PN process. The authors state, that the corrosion resistance of stainless steels can be impaired if the process of plasma nitriding is carried out at temperatures $450{ }^{\circ} \mathrm{C}$ [7], $460{ }^{\circ} \mathrm{C}$ for AISI 304 stainless steel [8], $475{ }^{\circ} \mathrm{C}$ [9] and $480^{\circ} \mathrm{C}$ [10]. For example, plasma nitrided AISI 410 steel at temperature $420^{\circ} \mathrm{C}$ for 6 hours obtained better corrosion resistance than the un-nitrided one [11]. On the other hand, same steel (AISI 410) plasma nitrided at temperature $500^{\circ} \mathrm{C}$ had been affected by decreased corrosion resistance [12].

It is stated that above threshold of $450^{\circ} \mathrm{C} \div 480^{\circ} \mathrm{C}$ (depends on type of steel) the precipitation of iron and chromium nitrides $(\mathrm{CrN})$ on the grain boundaries in case layer occurs [10]. At PN temperature of $500{ }^{\circ} \mathrm{C}$ the 
nitride layer consists of $\mathrm{CrN}, \mathrm{Fe}_{3} \mathrm{~N}$ and $\mathrm{Fe}_{4} \mathrm{~N}$ phases for $\mathrm{AISI} 304$ steel and the pitting corrosion was observed [8]. Similar behaviour was observed at $500{ }^{\circ} \mathrm{C}$ for plasma nitrided AISI 410 stainless steel as well [12].

\section{EXPERIMENTAL}

For the study was the X12Cr13 martensitic stainless steel (AISI 410), used for production of turbochargers. Chemical composition has been verified using the spectrometer Tasman Q4 and compared to inspection certificate, summarized in Table 1.

Table 1 Chemical composition of $\mathrm{X} 12 \mathrm{Cr} 13$ (wt. \%)

\begin{tabular}{|l|c|c|c|c|c|c|c|c|c|c|c|c|}
\hline & $\mathbf{C}$ & $\mathbf{S i}$ & $\mathbf{M n}$ & $\mathbf{C r}$ & $\mathbf{N i}$ & $\mathbf{M o}$ & $\mathbf{V}$ & $\mathbf{C u}$ & $\mathbf{W}$ & $\mathbf{N 2}$ & $\mathbf{P}$ & $\mathbf{S}$ \\
\hline Tasman Q4 & 0.11 & 0.3 & 0.54 & 12.91 & 0.36 & 0.07 & 0.05 & 0.12 & 1.14 & 0.02 & 0.08 & 0.01 \\
\hline
\end{tabular}

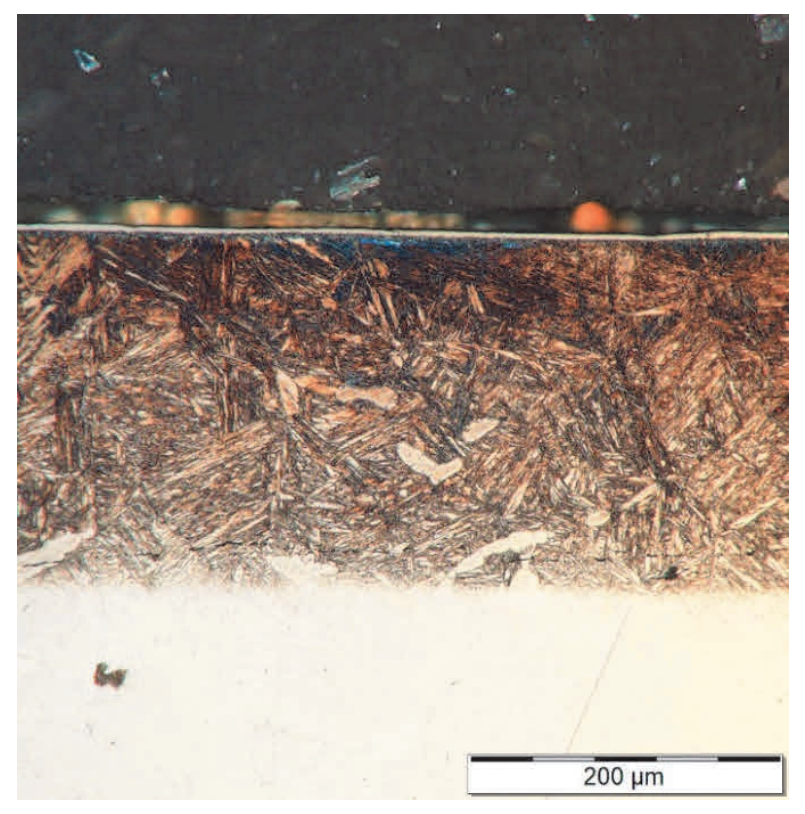

Figure 1 Microstructure of plasma nitrided X12Cr13 with visible compound and diffusion layer after etching by $5 \%$ Nital
For phase analysis were the original $70 \times 40 \mathrm{~mm}$ plasma nitrided and untreated turbochargers blades used, grinded to roughness of $\mathrm{Ra}=0,4 \mu \mathrm{m}$ by the manufacturer and then degreased in ethanol prior plasma nitriding process and before every measurement. The experimental material for specimens was in the form of blades of turbochargers. These were cut into samples for potentiodynamic polarization testing needed. Standard samples for potentiodynamic testing with diameter of $13 \mathrm{~mm}$ and thickness of $10 \mathrm{~mm}$ were prepared.

Prepared samples were subjected to plasma nitriding process with following plasma nitriding parameters: Operational nitriding atmosphere with gas ratio $3 \mathrm{H}_{2}: 1 \mathrm{~N}_{2}$ $(\mathrm{l} / \mathrm{h})$, time duration of nitriding process of 36 hours at temperature $520{ }^{\circ} \mathrm{C}$ in RUBIG PN 60/60 device.

Samples were studied by optical microscopy (OLYMPUS DSX 100). Existence of martensitic structure was observed in Figure 1. Thanks to etching by $5 \%$ Nital the diffusion layer and compound (white) layer were observed. Compound layer of approximately $3.69 \mu \mathrm{m}$ was measured using Olympus DSX 100.

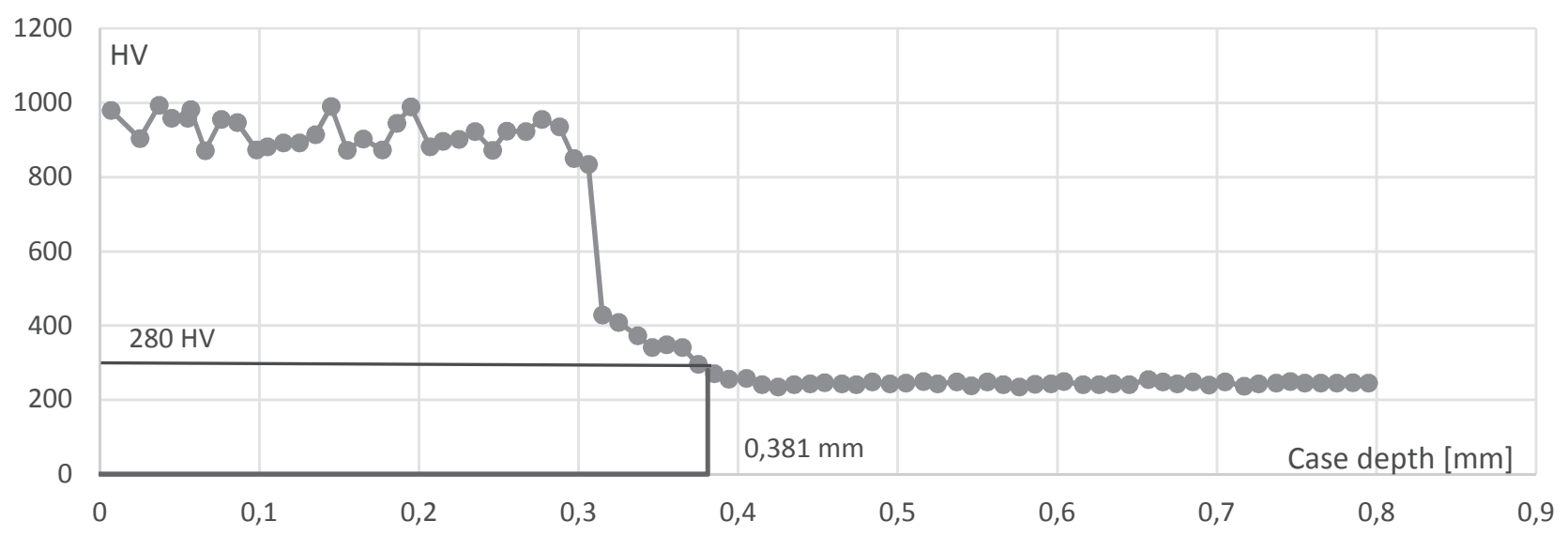

Figure 2 Microhardness measurement and nitride layer case depth evaluation 
The case layer depth reached $0.381 \mathrm{~mm}$, evaluated by microhardness measuring using LECO LM247 AT microhardness tester according to standard EN ISO 18203:2016 (see Figure 2).

Surface hardness was measured after plasma nitriding. Initial surface hardness of un-treated stainless-steel sample was measured $241 \pm 5 \mathrm{HV}$ and after plasma nitriding surface hardness increased to value $982 \pm 11$ HV.

Surfaces of plasma nitrided and untreated samples were additionally documented by the optical microscopy (OLYMPUS DSX 100) after anodic potentiodynamic polarization tests (see Figure 3). The pitting was evaluated using laser confocal microscopy LEXT OLS 3000 and pitting factor (PF) was calculated according to standard ISO 11463 for untreated and plasma nitrided X12Cr13 steel samples. The calculated pitting factor represents a ratio of deepest pit to the average depth of 10 measured pits. Pitting factor of value 1 indicates general corrosion and with increased value of pitting factor the pitting corrosion is more prominent.
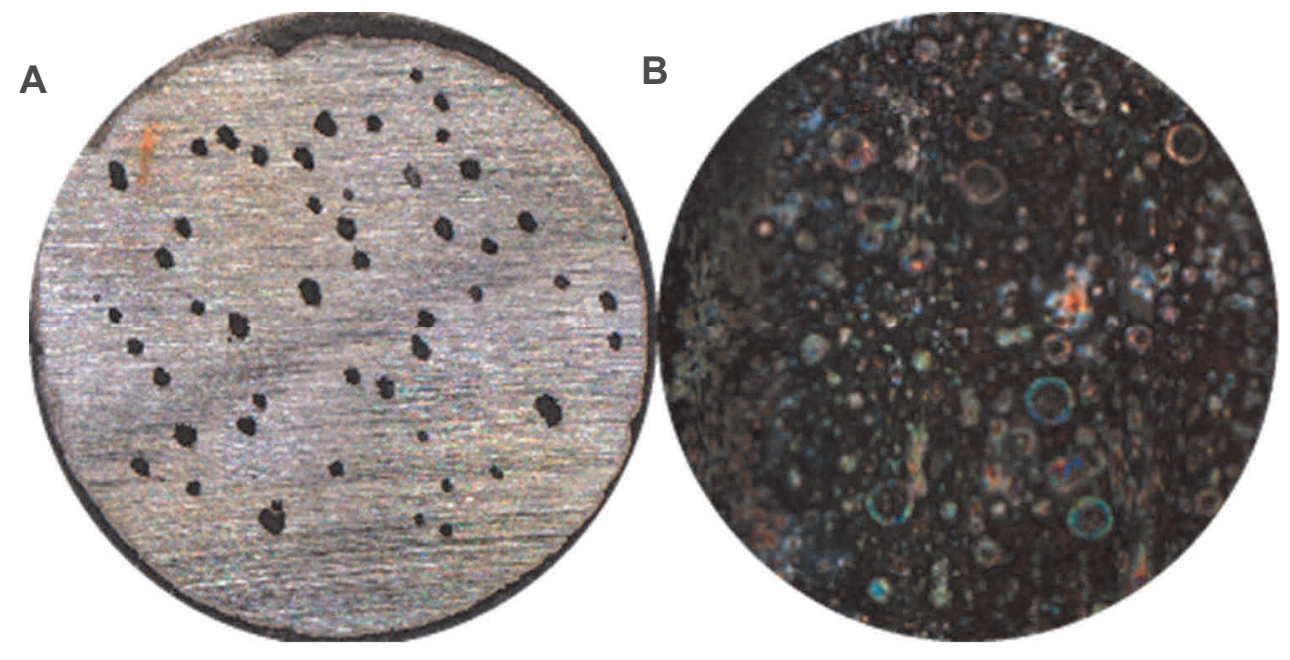

Figure 3 Pitting on the $\mathrm{X} 12 \mathrm{Cr} 13$ stainless steel after anodic potentiodynamic tests $(A)$ untreated, $(B)$ plasma nitrided

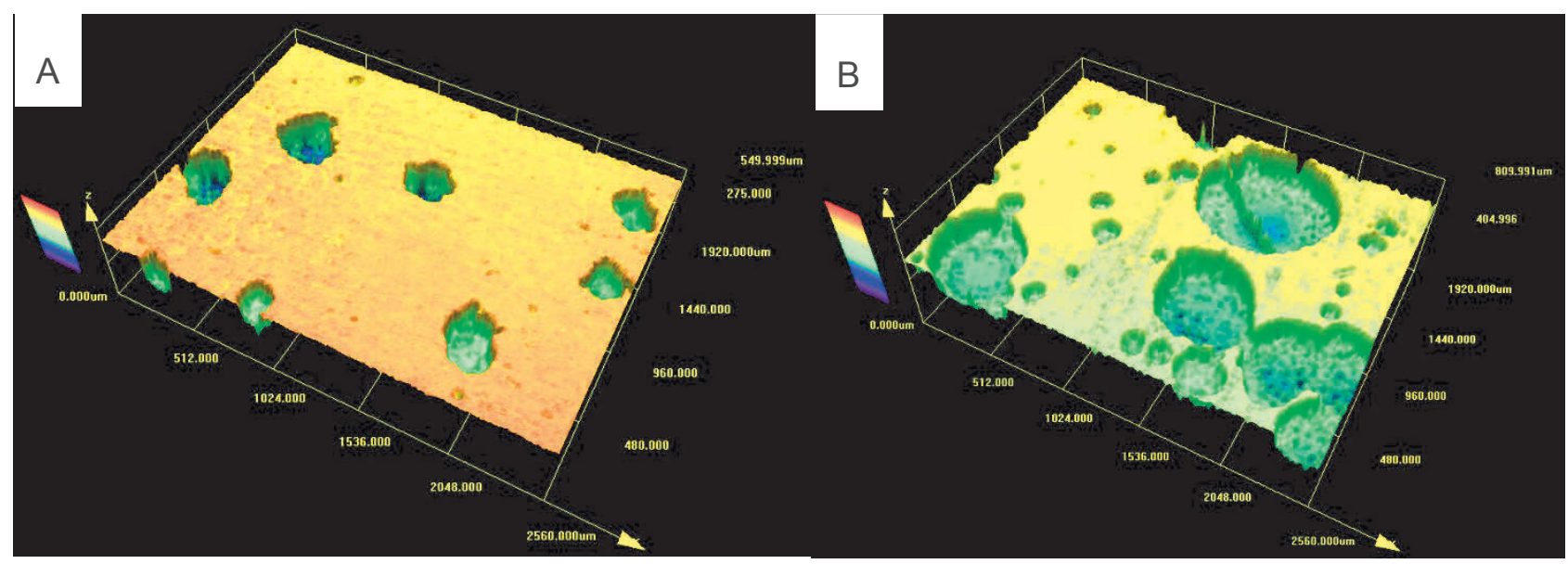

Figure 4 Pitting of X12Cr13 after potentiodynamic corrosion tests A - untreated steel, B - plasma nitrided steel (Laser confocal microscopy LEXT OLS 3000)

Pitting factor calculated for untreated stainless steel sample reached value of PF 1.21 and for plasma nitrided sample value of PF 1.87. The deepest hole of untreated and plasma nitrided samples values of $310 \mu \mathrm{m}$ and $341 \mu \mathrm{m}$ respectively were measured. Additionally, average width of holes for untreated samples reached value 
of $145 \mu \mathrm{m}$ and $207 \mu \mathrm{m}$ for plasma nitrided samples. The holes were observed by laser confocal microscopy LEXT OLS 3000 (see Figure 4).

Anodic potentiodynamic polarization tests were carried out on untreated and plasma nitrided samples of $\mathrm{X} 12 \mathrm{Cr} 13$ martensitic stainless steel. The Biologic SP 150 potentiostat as main measuring device with software EC-Lab V11.10. used for calculating values of corrosion characteristics. The Cyclic Potentiodynamic Polarization method (ASTM-61) was chosen as method for measuring chosen corrosion characteristics. Parameters of this method were following: sweep speed dE/dt $=0.166 \mathrm{mV} / \mathrm{s}, \mathrm{Ei}=-0.25 \mathrm{~V}, \mathrm{EL}=2 \mathrm{~V}, \mathrm{Ip}=25$ $\mathrm{mA}$, E range (-2 V;2 V) at ambient temperature. Measured surface of steel samples was $0.865 \mathrm{~cm}^{2}$. Samples were exposed to neutral deaerated $2.5 \% \mathrm{NaCl}$ solution. Anodic potentiodynamic measurement involves polarizing the working electrode (sample) from its equilibrium potential Eoc (OCP - open circuit potential), by steadily shifting DC potential difference between the working electrode and the counter electrode (Supersaturated Calomel Electrode) by the potentiostat, while recording the current response (see Figure 5.). The Tafels constants $\beta_{a}$ and $\beta_{c}$ and calculations represent average values of three measurements are summarized in Table 2.

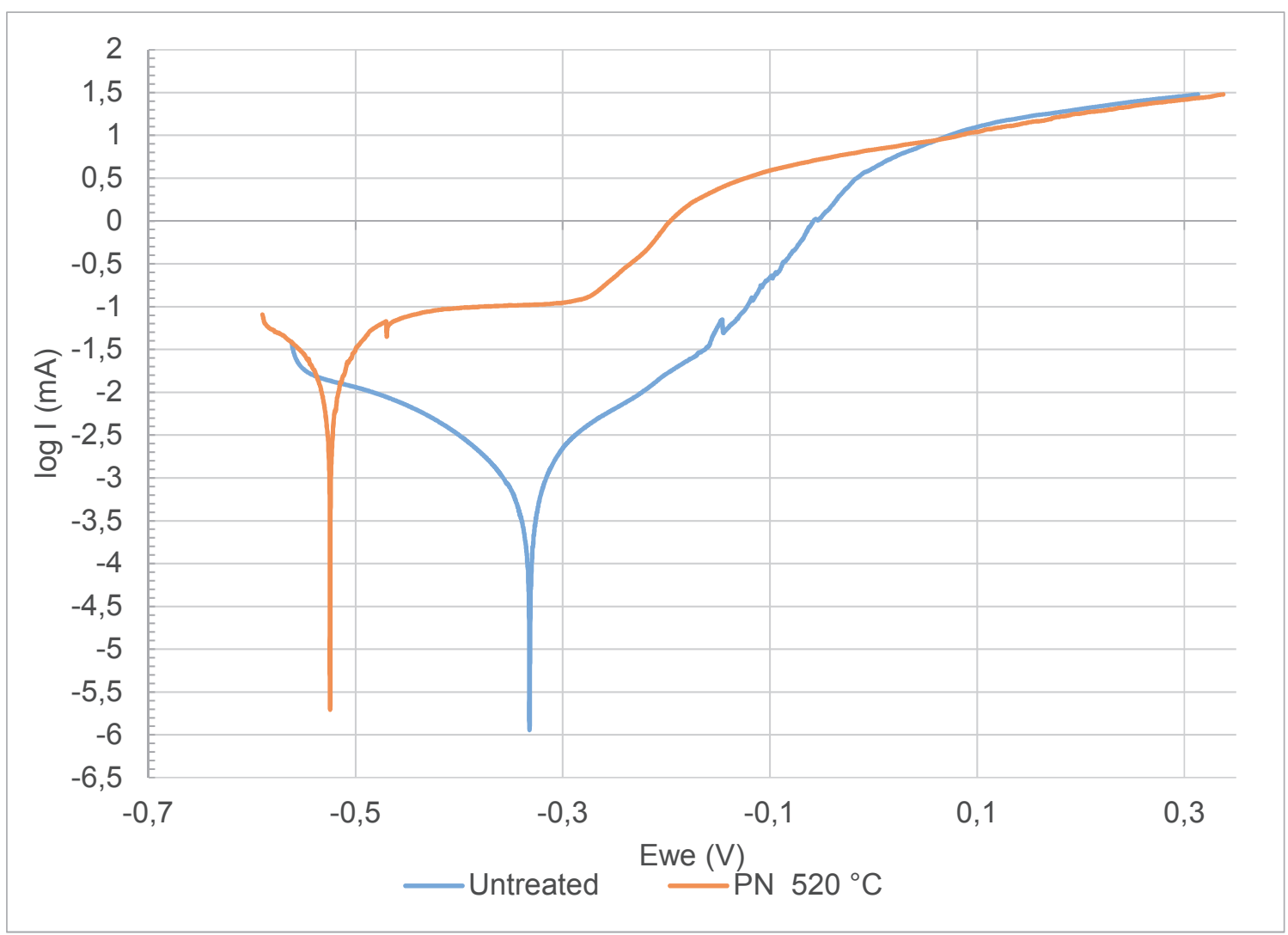

Figure 5 Potentiodynamic curves of $\mathrm{X} 12 \mathrm{Cr} 13$ stainless steel in deaerated $2.5 \% \mathrm{NaCl}$ solution. (orange line) Plasma nitrided at $520^{\circ} \mathrm{C}$, (blue line) untreated steel

Table 2 Results of potentiodynamic polarization tests on $\mathrm{X} 12 \mathrm{Cr} 13$ steel

\begin{tabular}{|c|c|c|c|c|c|}
\hline & Ecorr $(\mathbf{m V})$ & Icorr $(\mu \mathrm{A})$ & $\boldsymbol{\beta c}$ & $\boldsymbol{\beta a}$ & $\begin{array}{c}\text { vcorr } \\
\left(\mathbf{m m} \cdot \mathbf{a}^{-1}\right)\end{array}$ \\
\hline Untreated & -312.969 & 1.61 & 220.6 & 111.5 & 0.0204 \\
\hline Plasma nitrided & -589.111 & 64.71 & 119.3 & 11166.3 & 0.8232 \\
\hline
\end{tabular}


The phase analysis was performed by XRD Rigaku Miniflex 600 device (Rigaku D/teX Ultra 250, Cu Ka radiation), using PDXL software with PDF-2 and Crystallographic Open Database for the quantitative analysis. Results of phase analysis can be observed at Figure 6. There can be seen visible peaks of iron nitrideds $\varepsilon-\mathrm{Fe}_{2-3}(\mathrm{~N}, \mathrm{C})$ and $\mathrm{\gamma}-\mathrm{Fe}_{4} \mathrm{~N}$ and chromium nitrides $\mathrm{CrN}$ in the case of plasma nitrided sample. Only peak of base material $\alpha^{\prime}-\mathrm{Fe}$ can be seen in untreated sample.

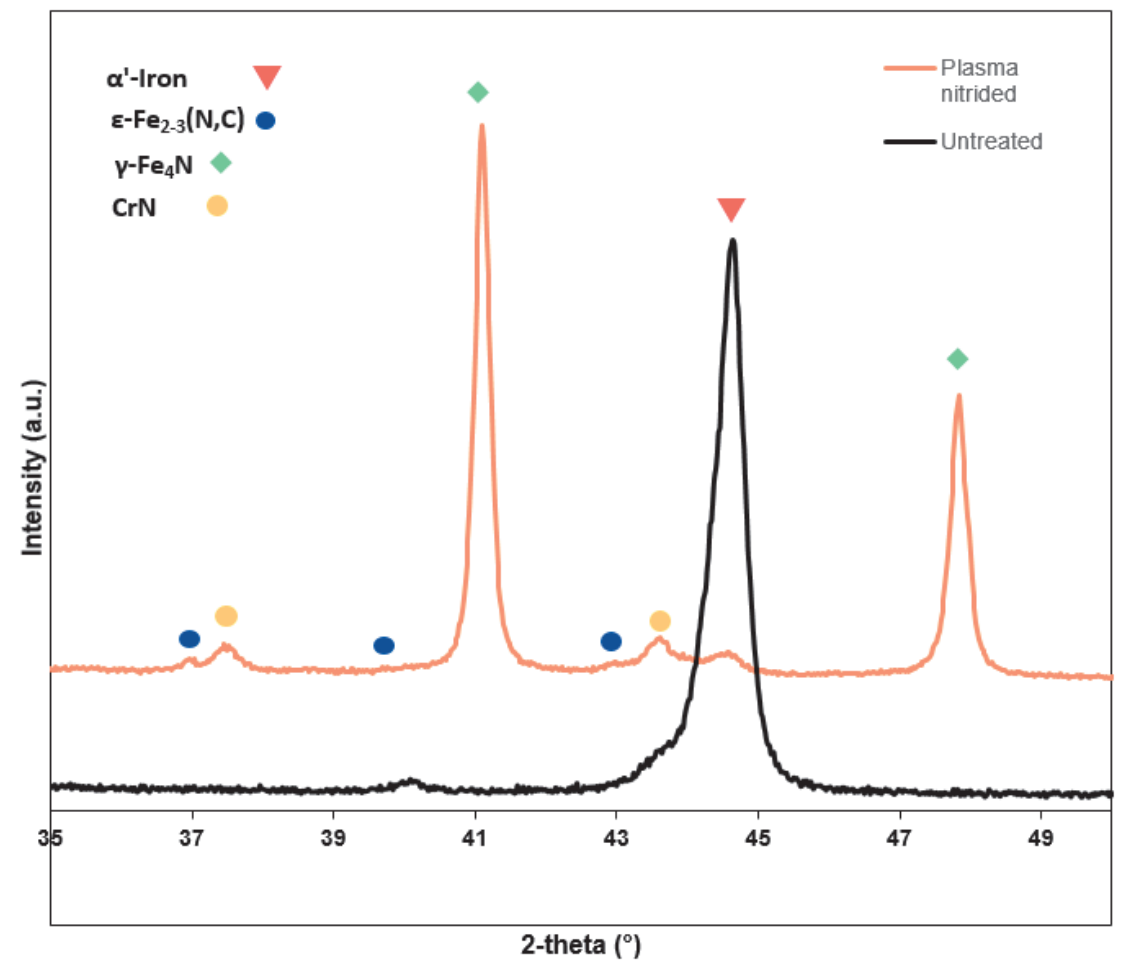

Figure 6 Phase Analysis of untreated and plasma nitrided X12Cr13 stainless steel

\section{CONCLUSION}

This paper describes corrosion resistance of plasma nitrided X12Cr13 (AISI 410) martensitic stainless steel evaluated using the anodic potentiodynamic tests in deaerated $2.5 \% \mathrm{NaCl}$ solution compared to untreated steel sample.

The high-temperature plasma nitriding increased surface hardness from $241 \pm 5 \mathrm{HV}$ to $982 \pm 11 \mathrm{HV}$ and created case layer of $0.381 \mathrm{~mm}$.

The corrosion resistance of untreated $\mathrm{X} 12 \mathrm{Cr} 13$ steel with value of corrosion rate $0.0204 \mathrm{~mm} \cdot \mathrm{a}^{-1}$ was approximately 40 times lower than corrosion resistance of plasma nitrided $\mathrm{X} 12 \mathrm{Cr} 13$ steel with value of corrosion rate $0.8232 \mathrm{~mm} \cdot \mathrm{a}^{-1}$.

According to calculated pitting factor (PF) can be concluded, the pitting for plasma nitrided steel was increased $(P F=1.87)$ compared to untreated steel (PF $=1.21)$, and even average width of pits for plasma nitrided steel $(207 \mu \mathrm{m})$ has increased compared to untreated one $(145 \mu \mathrm{m})$.

The presence of chromium nitrides $\mathrm{CrN}$ in plasma nitrided $\mathrm{X} 12 \mathrm{Cr} 13$ stainless steel indicate reduced chromium content in the solid solution because of precipitation of $\mathrm{CrN}$. That can be reason for lower corrosion resistance after plasma nitridation AISI 410 steel.

Summary, plasma nitridation of martensitic stainless steel at temperature of $520^{\circ} \mathrm{C}$ rapidly deteriorated the corrosion resistance in every aspect compared to untreated one. But, the surface hardness of plasma nitrided $\mathrm{X} 12 \mathrm{Cr} 13$ stainless steel was greatly increased. 


\section{ACKNOWLEDGEMENTS}

The present research work was supported by the project The Development of Technologies, Design of Firearms, Ammunition, Instrumentation, Engineering of Materials and Military Infrastructure "VÝZBROJ (DZRO K201)" and "Surface technology in applications special techniques SV18-216".

\section{REFERENCES}

[1] STUDENY, Z. Analysis of the Influence of Initiating Inclusions on Fatigue Life of Plasma Nitrided Steels. Journal Manufacturing Technology, 2015, vol. 15, no. 1, pp. 99-105.

[2] POKORNY, P., SZELAG, P., NOVAK, M., MASTNY, L., BROZEK, V. Thermal stability of phosphate coatings on steel. Metalurgija, vol. 54, issue 3, 2015, pp. 489-492.

[3] ESPITIA, L.A., Hanshan DONG, Xiao-Ying LI, C.E. PINEDO a A.P. TSCHIPTSCHIN. Scratch test of active screen low temperature plasma nitrided AISI 410 martensitic stainless steel. Wear [online]. 2017, 376-377, 30-36

[4] ROVANI, Ane C., Rogério BREGANON, Gismar S. DE SOUZA, Silvio F. BRUNATTO a Giuseppe PINTAÚDE. Scratch resistance of low-temperature plasma nitrided and carburized martensitic stainless steel. Wear [online]. 2017, 376-377, 70-76

[5] DOBROCKY, D., STUDENY, Z., POKORNY, Z., POSPICHAL, M. SMIDA, O. Effect of plasma nitriding on the notch toughness of spring steel. In: METAL 2016, 25th Anniversary International Conference on Metallurgy and Materials. Ostrava: TANGER 2016, pp. 1037-1044.

[6] KUSMIČ, David; ČECH, Ondřej; FALTEJSEK, Petr. Duplex treatment of plasma nitriding and manganese phosphating of $42 \mathrm{CrMo} 4$ steel for corrosion resistance increasing. In: 26TH ANNIVERSARY INTERNATIONAL CONFERENCE ON METALLURGY AND MATERIALS. Brno, Czech Republic: TANGER Ltd, 2018, p. 1077-1084. ISBN 978-808729479-6.

[7] YANG, W.J., M. ZHANG, Y.H. ZHAO, et al. Enhancement of mechanical property and corrosion resistance of 316L stainless steels by low temperature arc plasma nitriding. Surface and Coatings Technology[online]. 2016, 298, 64-72 [cit. 2017-10-12].

[8] LIANG, Wang. Surface modification of AISI 304 austenitic stainless steel by plasma nitriding. Applied Surface Science [online]. 2003, 211(1-4), 308-314 [cit. 2017-10-10].

[9] MENTHE, E. a K.-T. RIE. Further investigation of the structure and properties of austenitic stainless steel after plasma nitriding. Surface and Coatings Technology [online]. 1999, 116-119, 199-204

[10] LI, Yang, Zhuo WANG a Liang WANG. Surface properties of nitrided layer on AISI 316L austenitic stainless steel produced by high temperature plasma nitriding in short time. Applied Surface Science[online]. 2014, 298, 243-250

[11] LI, C.X. a T. BELL. Corrosion properties of plasma nitrided AISI 410 martensitic stainless steel in $3.5 \% \mathrm{NaCl}$ and $1 \% \mathrm{HCl}$ aqueous solutions. Corrosion Science [online]. 2006, 48(8), 2036-2049 [cit. 2019-01-23]. DOI: 10.1016/j.corsci.2005.08.011. ISSN 0010938X.

[12] CORENGIA, P, G YBARRA, C MOINA, A CABO a E BROITMAN. Microstructure and corrosion behaviour of DCpulsed plasma nitrided AISI 410 martensitic stainless steel. Surface and Coatings Technology[online]. 2004, 187(1), 63-69 [cit. 2019-01-23]. DOI: 10.1016/j.surfcoat.2004.01.031. ISSN 02578972. 